\title{
Physico-chemical characteristics of olive fruits of Turkish varieties from the province of Hatay
}

\author{
By D. Arslan*
}

\author{
Selcuk University, Faculty of Agriculture, Department of Food Engineering, 42030, Konya, Turkey \\ ${ }^{*}$ Corresponding author: dears@ $@$ selcuk.edu.tr
}

\section{RESUMEN}

Características físico-químicas de aceitunas de variedades turcas de la provincia de Hatay.

Aceitunas de cuatro variedades diferentes de la provincia de Hatay en Turquía (Kargaburun, Erkence, Halhalı y Saurani) fueron recogidas en tres periodos diferentes y analizadas con el fin de determinar los efectos tanto de la naturaleza de la variedad como del tiempo de la cosecha. Se llevaron a cabo las determinaciones analíticas de algunos parámetros físicos (número y peso de frutos, dimensiones, humedad, contenido de aceite e índice instrumental de color de los frutos) y químicos (compuestos fenólicos individuales, fenoles totales, actividad captadora de radicales DPPH, capacidad antioxidante equivalente Trolox y las composiciones en ácidos grasos) de los frutos. Para todas las variedades estudiadas, la oleuropeína fue el compuesto fenólico más abundante, presentando valores que van desde 41,39 hasta $159,73 \mathrm{mg} / \mathrm{kg}$, siendo los frutos de la variedad Sauranilos que presentaron los valores más altos. Las variedades Saurani y Kargaburun mostraron perfiles fenólicos característicos; Saurani por su gran cantidad de oleuropeína y Kargaburun por su alto nivel de $\mathrm{H}$-tirosol. Estas dos variedades presentaron la más alta capacidad antioxidante determinada como equivalentes Trolox, también los ácidos cítrico y succínico fueron los principales ácidos orgánicos determinados en las aceitunas. El nivel de fenoles totales en las aceitunas disminuye rápidamente cuando la fecha de cosecha progresa. Una tendencia general decreciente se observó también en los ácidos grasos saturados palmítico y esteárico, de los aceites de oliva con el aumento de la fecha de cosecha en las cuatro variedades estudiadas.

PALABRAS CLAVE: Aceitunas - Actividad antioxidante - Fenoles - Fecha de cosecha.

\section{SUMMARY}

Physico-chemical characteristics of olive fruits of Turkish varieties from the province of Hatay.

The olive fruits of four different Turkish varieties (Kargaburun, Erkence, Halhalı and Saurani) from the province of Hatay which were harvested on three different occasions have been analyzed in order to determine the effects of both the nature of the cultivar and the time of harvest. Analyses of some physical properties were carried out such as fruit and pit weight, size, moisture and oil contents and instrumental color index along with some chemical properties such as individual phenolic compounds, total phenolics, DPPH radical scavenging activity and Trolox equivalent antioxidant capacity and fatty acid composition. For all the varieties studied, oleuropein was the most abundant phenolic substance ranging from $41.39-159.73 \mathrm{mg} / \mathrm{kg}$, for which the Saurani variety had the highest level. Saurani and Kargaburun varieties were found to possess characteristic phenolic profiles: Saurani for its high amount of oleuropein and Kargaburun for its high level of $\mathrm{H}$-tyrosol.

These two varieties had higher Trolox equivalent antioxidant capacities as well. Citric and succinic acids were the main organic acids determined in the olive fruits. The level of total phenolics in the olive fruits declined rapidly with a later harvest date. A general decreasing trend was also observed in the saturated fatty acid (palmitic and stearic acids) concentrations of the olive oils with later harvest dates in the four varieties studied.

KEY-WORDS: Antioxidant activity - Harvest date - Olive fruits - Phenols.

\section{INTRODUCTION}

There is a total of 37,381 has of olive growing areas in the province of Hatay in Turkey, which has 5.2 million fruit bearing olive trees and 1.7 million non-bearing olive trees. 98,946 tons of olives and 21,988 tons of olive oil are produced in the province (ZAE, 2007). Hatay meets $7 \%$ of the table olive and $10 \%$ of the olive oil requirements of Turkey (DIE, 2008).

The most important olive varieties cultivated in Hatay are Halhalı, Saurani, Haşebi, Karamani, Sariulak and Gemlik (Dıraman, 2007). Kargaburun is consumed generally as table olives, Erkence, Saurani and Karamani are generally processed for olive oil and Halhalı and Haşebi varieties are used for both oil extraction and table olive purposes (Anonymous, 1991). These cultivars show alternate and high productivity and are characterized by low frost resistance, medium vigor and small-sized fruit (except Halhalı). The trees produce a large amount of fruit and with a relatively high oil yield (more than $45 \%$ in dry matter) (ZAE, 2007). During the last few years, new cultivars have been introduced in Hatay, especially the cultivar "Gemlik" which is widespread in the Aegean and Marmara regions of the country and occupies a great part of table olive and olive oil production with its high fruit and oil yield, early maturation, low periodicity and organoleptic quality which is highly valued by consumers. It is the most 
easily available cultivar for the local olive growers as $80 \%$ of seedlings produced by governmental and private companies belong to this cultivar. This led to a decline in the number of autochthonous cultivars in the province. However, before promoting new cultivars, their behavior in different environments should be evaluated (Dabbou et al., 2010). It is now known, for example, that the Gemlik variety, with its generally good plantation characteristics, did not adapt well to the environmental conditions of Hatay. This undesirable outcome was the result of faulty decision making on the part of governmental groups. An example is the omission of a necessary scientific evaluation of possible consequences.

The aim of this work was, therefore, to determine the effect of both (i) the nature of the cultivar and (ii) the harvesting time of the olive fruit on the phenolics and organic acids together with DPPH radical scavenging and Trolox equivalent antioxidant capacity in four different Turkish varieties: 'Kargaburun', 'Erkence', 'Halhalı' and 'Saurani'. 'Kargaburun', 'Erkence', 'Halhalı' and 'Saurani' are the main varieties being cultivated in the Hatay area. Data on the chemical composition of these olive varieties is scarce. Changes in fruit growth and composition due to ripening have also been studied in order to improve the knowledge concerning the ripening of these olive varieties. In addition, each variety can be directed to the most proper way of processing by reporting its physical and chemical characteristics.

\section{MATERIALS AND METHODS}

\subsection{Olive origin}

Olives of the Kargaburun variety were harvested three times in Antakya-Oğlakören, Erkence in Dörtyol, Halhalı in Altınözü and Saurani in Reyhanlı- Cilvegözüyolu in Hatay, Turkey (Fig. 1). Olive sampling dates were: (HD) from September 15 th to October $1^{\text {st }}$, (1. HD) from October 20th to November $1^{\text {st }},(2$. HD) and from November 20th

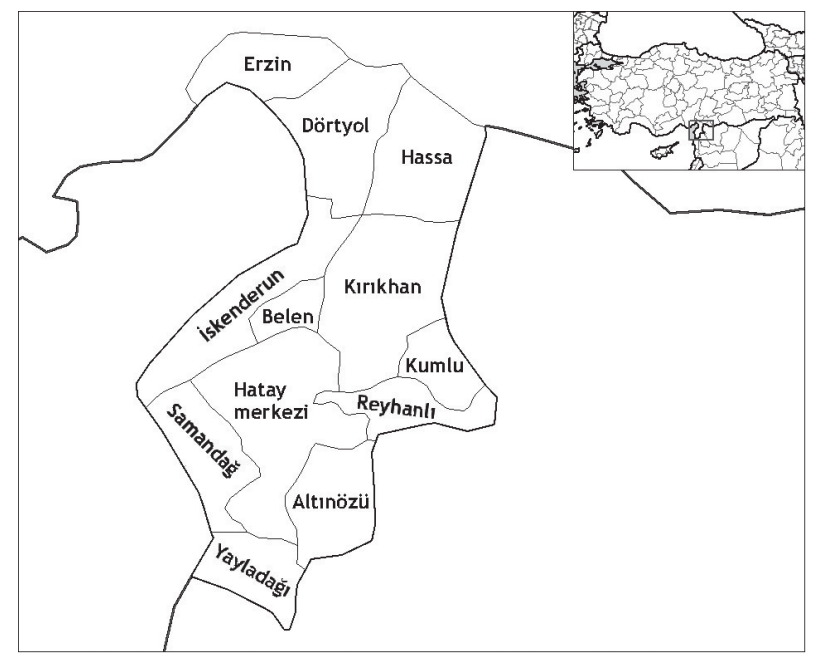

Figure 1

City of Hatay: the growing area of the different varieties studied. to December $1^{\text {st }}(3$. HD) in the year 2007. The olive fruits were collected from at least three orchards which were subjected to the same agronomic processes. From each variety, three $5 \mathrm{~kg}$ samples of fruits were taken from each orchard. After harvest, the fruits were then stored in a fridge $\left(4 \pm 0.5^{\circ} \mathrm{C}\right)$ for 5 days. Prior to mechanical measurements the fruits were left at room temperature for $30 \mathrm{~min}$. The ripening index $(\mathrm{RI})$ of the olive fruit was determined according to Artajo et al. (2006) based on an evaluation of the olive skin and pulp colors.

\subsection{Physical and chemical parameters}

The average weights of samples were determined by measuring the weights of 30 olive fruits and their pits. 3 measurements were made on 30 fruits for their thickness, width and length using a caliper (Mitutoyo Corp. Model no SC-6, Japan) and their average values were considered. Some of the chemical and physical properties (moisture, fruit and pit weight) of the olives were analyzed according to AOAC (1990). The total oil content was determined by using a Soxhlet extractor for $8 \mathrm{~h}$ with petroleum ether after drying $50 \mathrm{~g}$ of olive flesh at $100^{\circ} \mathrm{C}$ for $24 \mathrm{~h}$, and the results are given as percentage of dry weight (Zamora et al., 2001).

\subsection{Extraction of phenolic compounds}

The phenolic extracts of the olive paste were obtained using the method of Vinha et al. (2005) with modifications. The extraction, purification and separation were done as follows: $1.5 \mathrm{~g}$ of sample were extracted with $20 \mathrm{~mL}$ of 80:20 (v/v) methanolwater. The mixture was homogenized using an Ultraturrax homogenizer (IKA, Germany), centrifuged at $3000 \mathrm{rev} / \mathrm{min}$ for $5 \mathrm{~min}$ and the supernatant was filtered through filter paper. The pellet was reextracted as above. The purification was carried out with $10 \mathrm{~mL}$ of $n$-hexane in order to eliminate the residual oil of the resulting methanolic extract. The separation of the phases was performed with separating funnels. The methanolic extracts were combined (phenolic extract) and injected for HPLC analysis.

\subsection{HPLC analysis of phenolic compounds}

The extracted phenolic fractions were analyzed by HPLC (injection $40 \mu \mathrm{L}$ ). The HPLC system included an LC 10A vp, an LC-20AT prominence pump, a CTO-10AS VP heater (column temperature $30^{\circ} \mathrm{C}$ ), an SIL-20A prominence auto sampler and an SPD-M20A Prominence diode-array detector (Shimadzu, Kyoto, Japan). The column was an Inertsil ODS-3 $(5 \mu \mathrm{m}, 25 \mathrm{~cm} \times 4.6 \mathrm{~mm}$ i.d.) (GL Sciences, Tokyo, Japan). PC running Class VP chromatography manager software (Shimadzu, Japan) was used and chromatograms were obtained at 280 and $320 \mathrm{~nm}$. The following gradient 
program was employed (in $\%): t=0 \mathrm{~min}, \mathrm{~A}(2 \%$ formic acid, vol/vol), B (methanol) $=95 / 5$; $t=3 \mathrm{~min}$, $A / B=85 / 15 ; t=13 \mathrm{~min}, A / B=80 / 20 ; t=25 \mathrm{~min}$, $A / B=75 / 25 ; t=35 \mathrm{~min}, A / B=70 / 30 ; t=40 \mathrm{~min}$, $A / B=65 / 35 ; t=45 \mathrm{~min}, A / B=60 / 40 ; t=47 \mathrm{~min}$, $A / B=55 / 45 ; t=50 \mathrm{~min}, A / B=53 / 47 ; t=60 \mathrm{~min}$, $A / B=52 / 48 ; t=64 \mathrm{~min}, A / B=50 / 50 ; t=64 \mathrm{~min}$, $A / B=0 / 100$, held for 6 min, followed by returning to the starting ratio (for $5 \mathrm{~min}$ ). The flow rate was $0.85 \mathrm{~mL} / \mathrm{min}$ and the injection volume was $40 \mu \mathrm{L}$. The total run time was 76 min. Individual phenols were quantified by a four-point regression curve on the basis of standards obtained from commercial suppliers. The individual phenols of olive paste are expressed as $\mathrm{mg} \mathrm{kg}^{-1}$.

Reference compounds: Oleuropein and hydroxytyrosol (H-tyrosol) were obtained from Extrasynthĕse (Genay, France) and cinnamic acid, vanillic acid, $p$-coumaric acid, ferulic acid, apigenin, tyrosol, caffeic acid and taxifolin from Fluka (Steinheim, Germany), rut in from Sigma-Aldrich (Steinheim, Germany).

\subsection{Total phenol content}

The total phenol content of methanolic extracts was analyzed using the modified isolation method described by VázquezRoncero et al., (1973). The concentration of total polyphenols was estimated with Folin-Ciocalteau reagent at $725 \mathrm{~nm}$. The results were expressed as $\mathrm{mg}$ of gallic acid per $\mathrm{kg}$ of olive paste.

\subsection{Color analyses}

The color of the olive fruits was measured by Minolta Chroma meter CR 400 color meter (Minolta Co., Osaka, Japan). The color meter was calibrated against a standard calibration plate of a white surface and set to CIE Standard Illuminant C. The $L^{*}, a^{*}, b^{*}$ values are the averages of ten readings. The color brightness coordinate $L^{*}$ measures the whiteness value of a color and ranges from black at 0 to white at 100 . The chromaticity coordinate $a^{*}$ measures red when positive and green when negative and the chromaticity coordinate $b^{*}$ measures yellow when positive and blue when negative (Romero et al., 2002).

\subsection{HPLC analysis of organic acids}

For organic acid extraction, approximately $500 \mathrm{~g}$ of each frozen sample were used, then from this homogenized material $1 \mathrm{~g}$ of sample was weighed and powdered with liquid nitrogen in a mortar and mixed with $20 \mathrm{~mL}$ of aqueous meta-phosphoric acid (3\%) at room temperature for 30 min using a shaker. This mixture was filtered and made up to $25 \mathrm{~mL}$ with the same solvent, then used for HPLC analysis. The HPLC apparatus (Shimadzu LC 10A vp, Kyoto, Japan) consisted of an in-line degasser (DGU20A5) pump and controller coupled to a PDA
(Shimadzu SPD-M20 A) equipped with an automatic injector $(20 \mu \mathrm{L}$ injection volume) interfaced to a PC running Class VP chromatography manager software (Shimadzu, Japan). Separations were performed on a $250 \mathrm{~mm} 4.6 \mathrm{~mm}$ i.d., $5 \mu \mathrm{m}$, reversephase Inertsil ODS3 analytical column operating at $30{ }^{\circ} \mathrm{C}$ (column oven CTO-10AS vp) with a flow rate of $0.5 \mathrm{~mL} / \mathrm{min}$. Detection was carried out between the wavelengths of 200 and $360 \mathrm{~nm}$. Elution was isocratic with $0.5 \%$ aqueous meta-phosphoric acid. Components were identified by comparison of their retention times to those of authentic standards under analysis conditions and UV spectra with an in-house PDA library. A 10 min equilibrium time was allowed between injections. All the samples were directly injected to the reverse phase chromatography column. For the stock solution of the organic acid standards, L-ascorbic acid, malic acid, tartaric acid and citric acid were dissolved in methanol at a concentration of $1 \mathrm{mg} / \mathrm{mL}$. All samples and standards were injected three times each and mean values were used (Kafkas et al., 2006).

\subsection{DPPH radical scavenging activity}

Antioxidant activity was evaluated by measuring the radical scavenging effect of methanolic extracts of the olive fruits towards the 2,2-diphenyl-1picrylhydracyl $\left(\mathrm{DPPH}^{\bullet}\right)$ as reported previously by Singh et al.(2002). Five milliliters of a $0.1 \mathrm{~mm}$ methanol solution of DPPH (Fluka) were added to 0.1 mLof several concentrations of methanol extracts of fresh and dried tomato samples. The tubes were allowed to stand at $27^{\circ} \mathrm{C}$ for $20 \mathrm{~min}$. The decrease in absorbance at $517 \mathrm{~nm}$ was recorded in a spectrophotometer (Shimadzu UV-vis mini spectrophotometer 1240). Radical scavenging activity was expressed as inhibition percentage and was calculated using the following formula:

$$
\begin{gathered}
\text { Percent radical scavenging activity }= \\
=(\text { control OD }- \text { sample OD / control OD }) \times 100 \text {. }
\end{gathered}
$$

\subsection{Total antioxidant activity assay}

Total antioxidant activity was determined using the ABTS method adapted from Miller and RiceEvans (1997). Decolorization of the $\mathrm{ABTS}^{\bullet+}$ radical cation by sample extract was measured at $734 \mathrm{~nm}$ in relation to a Trolox ${ }^{\circledR}$ (6-hydroxy-2,5,7,8-tetramethylchroman-2-carboxylic acid, Sigma-Aldrich) standard. Results were expressed as Trolox ${ }^{\circledR}$ equivalent antioxidant capacity ( $\mathrm{mmol}$ TEAC/ $\mathrm{kg}$ ).

\subsection{Fatty Acid Analysis}

For the determination of fatty acid composition of the oils, fatty acid methyl esters were prepared from olive oil, using a cold transmethylation (Stefanoudaki et al., 1999). The fatty acids were converted to fatty acid methyl esters before analysis 
by shaking a solution of $0.2 \mathrm{~g}$ oil and $3 \mathrm{~mL}$ of hexane with $0.4 \mathrm{~mL}$ of $2-\mathrm{N}$ methanolic potassium hydroxide. A Shimadzu (Kyoto, Japan) gas chromatograph, equipped with a flame ionization detector and a split/splitless injector, was employed. Separations were made on a Teknokroma TR-CN100 (Barcelona, Spain) fused-silica capillary column (60 $\mathrm{m} \times 0.25 \mathrm{~mm}$ i.d. $\times 0.20 \mu \mathrm{m}$ film thickness). The carrier gas was nitrogen, with a flow rate of $1 \mathrm{~mL} / \mathrm{min}$. The temperatures of the injector and the detector were held at 220 and $250^{\circ} \mathrm{C}$, respectively. The initial oven temperature of $90^{\circ} \mathrm{C}$ was maintained for $7 \mathrm{~min}$., raised to $240^{\circ} \mathrm{C}$ at a rate of $5^{\circ} \mathrm{C}$ per min, where it was held for $15 \mathrm{~min}$. The injection volume was $1 \mu \mathrm{L}$. The peaks were identified by comparison of their retention times with those of authentic reference compounds (Sigma-Aldrich, St. Louis, MO, USA).

\subsection{Statistical analysis}

The data were subjected to ANOVA using SPSS 10.0 for Windows. Separation of the means was obtained using the Duncan's test, and significant difference was defined as $P<0.05$.

\section{RESULTS AND DISCUSSION}

\subsection{Physical and chemical parameters}

The average values obtained for the physical and chemical parameters analyzed in the fruits are given in Table 1. There were significant differences between the physical properties and chemical constituents of the olive varieties used in the assay except for the color CIE $L^{*} a^{*} b^{*}$ parameters. $L^{*}$ values of the fruits increased for the third HD, as the color of the fruits was getting darker with ripening. $a^{*}$ values significantly increased and became positive when the fruits ripened at the second and third HDs. A clear decrease in the $b^{*}$ values during fruit ripening was observed which showed that yellowness decreased. The $a^{*}$ and $b^{*}$ values of the olive fruits were also reported to increase and decrease respectively with ripening in a previous study by Criado et al., (2007).

The dry matter values of the fruits ranged between 36.6 and $56.7 \%$ in the first HD, 43.9 and $52.0 \%$ in the second HD and 42.3 and $55.9 \%$ in the third HD. The dry matter content of the fruits reached its highest levels at the third $H D$, except for the Erkence variety for which the dry matter content did not statistically differ among HDs.

The total oil contents of the four varieties ranged between 45.1 and $65.0 \%$ in dry matter. On comparing the results according to varieties, Kargaburun and Saurani varieties had the highest dry matter and total oil contents. The oil content of Kargaburun fruits showed the lowest level in the first and the highest level in the second HD, whereas the differences in oil content of fruits from other varieties according to HDs were not statistically significant. It was also reported in previous studies that the total oil content did not show big changes as a function of the ripening state (García et al., 1996; Zamora et al., 2001). However, on the contrary, in some studies it was claimed that the total oil content of the Mission variety grown in Japan increased from $24.5 \%$ to $40.5 \%$ between October and December (Shibasaki, 2005). The total oil content $(\%)$ in the dry matter of Picual variety olive fruits from Spain were reported between 35.3 and 52.3 by Rial and Falque (2003). This ratio was reported as $52.8,58.3$ and $40.0 \%$ for $\mathrm{Hd} \mathrm{034,} \mathrm{Hd}$ 039 and the Chemlali varieties grown in Tunisia (Manai et al., 2007), as 61.93, 50.20 and 59.77\% for the Frantoio, Hojiblanca and Picual varieties grown in Spain (Beltran et al., 2004) and as 33.5, 29.0 and $47.0 \%$ for the Meski, Sayali and Picholine varieties grown in Tunisia (Sakouhi et al., 2008), respectively. The results obtained here are in the range of previously reported values. Taking into account that the olive varieties which contain more than $46 \%$ total oil in dry matter are classified as high oil containing varieties (Tous and Romero, 1994); the four Turkish varieties studied can also be included in this group.

The pit and pulp weight values $(\mathrm{g})$ of the olives ranged from $0.39-0.79$ and $0.92-2.51$, respectively. The average pit weight of the Kargaburun variety was higher than the other varieties, but the pulp weight of the fruits of this variety was the lowest among the others. The fruit and pit weights $(\mathrm{g})$ of the Picual variety olives grown in Spain were reported as from 1.5 to 4.9 and 0.3 to 0.4 , respectively, by Rial and Falque (2003). Sakouhi et al. (2008) reported the fruit and pit weight (g) values as 6.4, 4.0, 5.0 and 1.7, 1.5, 1.4 for the Tunisian varieties Meski, Sayali and Picholine, respectively. The fruit and pit weights of the fruits of the four varieties studied here were lower than the values reported by Rial and Falque (2003) and Sakouhi et al., (2008). The fruit width and thickness of the fruits of Kargaburun variety were the highest, but their average length was the lowest among the other fruits. The fruits of Saurani had the highest pit and pulp weights. The pit and pulp weight, fruit width, thickness and length values of all the varieties were not statistically affected by harvest time.

\subsection{Total phenol content, antioxidant and radical scavenging activity}

The DPPH radical scavenging activity (low $I C_{50}$ ) of the Erkence fruit extracts was higher than the values for other varieties (Table 1). Nevertheless, there were not clear differences among the DPPH radical scavenging activities of the methanolic extracts of the four varieties used in this assay. The DPPH values of the methanol extracts of the fruits were lower at the first HD, which shows that immature fruits had higher radical scavenging activities.

The fruits of the third HD had higher TEAC values, while in the case of the Halhalı variety, the 
Table 1

Physical and chemical properties of olive fruit samples

\begin{tabular}{|c|c|c|c|c|c|c|c|c|c|c|c|c|}
\hline & \multicolumn{12}{|c|}{ Varieties } \\
\hline & \multicolumn{3}{|c|}{ Kargaburun } & \multicolumn{3}{|c|}{ Erkence } & \multicolumn{3}{|c|}{ Halhalı } & \multicolumn{3}{|c|}{ Saurani } \\
\hline & $1\left(\mathrm{RI}^{\dagger}=1.5\right)$ & $2(\mathrm{RI}=3.5)$ & $3(\mathrm{RI}=5.5)$ & $1(\mathrm{RI}=1)$ & $2(R \mid=4)$ & $3(\mathrm{RI}=6)$ & $1(\mathrm{Rl}=1)$ & $2(\mathrm{RI}=3.5)$ & $3(\mathrm{RI}=5.9)$ & $1(\mathrm{Rl}=2)$ & $2(\mathrm{RI}=4)$ & $3(\mathrm{RI}=6)$ \\
\hline Dry matter (\%) & $56.7 \pm 0.8^{*} a$ & $52.0 \pm 1.2 b$ & $55.9 \pm 0.8 a$ & $50.5 \pm 1.7$ & $50.9 \pm 1.5$ & $50.1 \pm 4.0$ & $36.6 \pm 0.5 b$ & $43.9 \pm 1.5 a$ & $42.3 \pm 0.5 a$ & $50.8 \pm 0.7$ & $49.3 \pm 0.4$ & $52.1 \pm 1.8$ \\
\hline Total oil (\%) & $45.1 \pm 0.9 c$ & $65.0 \pm 3.7 a$ & $54.3 \pm 2.4 b$ & $46.5 \pm 3.2$ & $46.4 \pm 0.7$ & $46.4 \pm 0.3$ & $47.4 \pm 3.0$ & $47.4 \pm 1.6$ & $49.2 \pm 2.6$ & $55.5 \pm 5.9$ & $47.9 \pm 0.8$ & $52.4 \pm 3.7$ \\
\hline Pit weight (g) & $0.7 \pm 0.1$ & $0.8 \pm 0.1$ & $0.8 \pm 0.1$ & $0.4 \pm 0.1$ & $0.5 \pm 0.0$ & $0.4 \pm 0.1$ & $0.4 \pm 0.0$ & $0.4 \pm 0.0$ & $0.5 \pm 0.1$ & $0.7 \pm 0.0$ & $0.7 \pm 0.1$ & $0.6 \pm 0.1$ \\
\hline Pulp weight (g) & $1.1 \pm 0.2$ & $1.0 \pm 0.2$ & $0.9 \pm 0.1$ & $1.5 \pm 0.6$ & $1.7 \pm 0.5$ & $1.4 \pm 0.3$ & $2.4 \pm 0.3$ & $1.9 \pm 0.4$ & $1.9 \pm 0.8$ & $2.1 \pm 0.3$ & $2.5 \pm 0.4$ & $2.5 \pm 0.4$ \\
\hline $\mathrm{DPPH}\left(\mathrm{IC}_{50}\right)$ & $1.0 \pm 0.1 b$ & $1.6 \pm 0.2 a$ & $0.9 \pm 0.1 b$ & $0.5 \pm 0.0 \mathrm{c}$ & $0.6 \pm 0.0 \mathrm{~b}$ & $0.8 \pm 0.0 \mathrm{a}$ & $0.6 \pm 0.1 b$ & $1.3 \pm 0.1 a$ & $1.5 \pm 0.2 \mathrm{a}$ & $0.8 \pm 0.1 c$ & $1.2 \pm 0.1 b$ & $1.5 \pm 0.1 \mathrm{a}$ \\
\hline TEAC (mmol TE/kg) & $1.7 \pm 0.2 b$ & $2.0 \pm 0.2 b$ & $2.4 \pm 0.2 \mathrm{a}$ & $1.1 \pm 0.1 \mathrm{a}$ & $0.9 \pm 0.0 b$ & $1.9 \pm 0.2 \mathrm{a}$ & $1.6 \pm 0.1 b$ & $2.3 \pm 0.1 a$ & $0.8 \pm 0.0 \mathrm{c}$ & $2.6 \pm 0.3 b$ & $1.6 \pm 0.3 b$ & $2.4 \pm 0.3 a$ \\
\hline $\begin{array}{l}\text { Total phenolics } \\
\text { (mggallic acid/ kg } \\
\text { fresh fruit) }\end{array}$ & $258.0 \pm 19.1 \mathrm{a}$ & $254.6 \pm 18.6 a$ & $184.7 \pm 21.4 b$ & $203.1 \pm 13.3 \mathrm{a}$ & $188.0 \pm 11.1 b$ & $181.3 \pm 21.6 \mathrm{~b}$ & $231.3 \pm 27.2 b$ & $189.6 \pm 12.1 b$ & $178.5 \pm 20.0 \mathrm{~b}$ & $246.0 \pm 16.4 a$ & $222.0 \pm 24.3 a b$ & $189.5 \pm 21.0 b$ \\
\hline$L^{*}$ & $58.8 \pm 3.7 a$ & $39.0 \pm 6.6 b$ & $26.6 \pm 1.9 c$ & $64.6 \pm 2.9 a$ & $32.7 \pm 2.4 b$ & $29.7 \pm 1.5 b$ & $67.3 \pm 3.2 \mathrm{a}$ & $34.8 \pm 3.6 \mathrm{~b}$ & $24.9 \pm 0.8 c$ & $67.6 \pm 4.0 \mathrm{a}$ & $34.4 \pm 3.9 b$ & $29.0 \pm 2.2 b$ \\
\hline$a^{*}$ & $-17.7 \pm 2.4 b$ & $8.4 \pm 1.3 a$ & $10.5 \pm 2.6 \mathrm{a}$ & $-19.8 \pm 1.3 b$ & $9.2 \pm 2.9 a$ & $8.4 \pm 3.3 a$ & $-19.5 \pm 0.7 b$ & $10.8 \pm 3.5 a$ & $8.8 \pm 4.1 a$ & $-20.1 \pm 1.9 b$ & $9.6 \pm 2.6 \mathrm{a}$ & $8.0 \pm 3.1 a$ \\
\hline$b^{*}$ & $33.5 \pm 4.0 \mathrm{a}$ & $7.1 \pm 4.4 b$ & $4.7 \pm 1.3 b$ & $41.5 \pm 2.4 a$ & $3.5 \pm 0.9 b$ & $2.3 \pm 0.5 b$ & $43.5 \pm 0.8 \mathrm{a}$ & $7.0 \pm 1.1 b$ & $0.9 \pm 0.4 c$ & $44.5 \pm 2.8 \mathrm{a}$ & $7.4 \pm 2.9 b$ & $2.1 \pm 1.9 c$ \\
\hline Fruit width (mm) & $12.2 \pm 0.9$ & $11.6 \pm 0.8$ & $14.3 \pm 2.6$ & $12.7 \pm 0.2$ & $14.4 \pm 1.0$ & $13.1 \pm 1.5$ & $14.2 \pm 1.1 b$ & $15.7 \pm 0.5 a b$ & $16.3 \pm 0.5 a$ & $15.9 \pm 0.4$ & $15.6 \pm 1.5$ & $14.0 \pm 0.5$ \\
\hline Fruit thickness (mm) & $12.1 \pm 0.7$ & $11.2 \pm 0.6$ & $12.9 \pm 1.0$ & $13.1 \pm 0.8$ & $13.8 \pm 0.9$ & $12.4 \pm 0.5$ & $13.8 \pm 1.0$ & $15.4 \pm 1.9$ & $14.5 \pm 1.0$ & $16.1 \pm 0.6$ & $15.8 \pm 1.5$ & $15.1 \pm 1.6$ \\
\hline Length (mm) & $21.8 \pm 1.9$ & $22.2 \pm 2.3$ & $21.7 \pm 2.3$ & $19.5 \pm 2.1$ & $17.6 \pm 2.5$ & $18.3 \pm 2.1$ & $18.0 \pm 0.5$ & $18.0 \pm 1.1$ & $20.3 \pm 1.3$ & $20.3 \pm 0.7$ & $19.9 \pm 1.8$ & $19.6 \pm 2.3$ \\
\hline
\end{tabular}

${ }^{*}$ mean \pm standard deviation, ${ }^{\dagger} \mathrm{RI}=$ Ripening index.

fruits of the second harvest had the highest TEAC values. On the contrary to DPPH radical scavenging activity, the immature fruits possessed lower antioxidant capacity. Saurani variety had the highest TEAC, while Erkence fruits showed the lowest antioxidant activity. Kargaburun fruits followed the Saurani variety in terms of TEAC. These two varieties had higher amounts of total phenolics and individual phenolics, which can be related to their higher TEAC.

The total phenols in the fruits ranged between 178.7 and $258.0 \mathrm{mg}$ gallic acid/kg fresh fruit. The total phenolic contents of Kargaburun and Saurani fruits were higher than the values of Halhalı and Erkence varieties. Ocakoğlu et al., (2009) reported the total phenolics content of the oil from the Erkence variety from the Aegean region of Turkey as $300 \mathrm{mg} / \mathrm{kg}$. The origin of the plantation might effect the high levels of phenolics even in oils of this variety reported by Ocakoğlu et al., (2009). The total phenolics in the fruits decreased throughout fruit maturation, whereas it did not show a significant change during the course of ripening for Erkence fruits. The decrease in phenolic content during the maturation of olive fruit was reported in several previous works (Cerretani et al., 2004; Shibasaki, 2005).

\subsection{Phenolic constituents}

The HPLC chromatogram of a fruit sample is reported as an example in Fig. 2. The main phenolic components found in the olive fruits studied were oleuropein, H-tyrosol, 4-hydroxyphenyl acetic acid (h-phenyl acetic acid), luteolin and tyrosol in descending order (Table 2). For all the varieties studied, oleuropein was the most abundant phenolic substance ranging from $41.39-159.73 \mathrm{mg} / \mathrm{kg}$. Servili et al. (1999) and Gómez-Rico et al. (2008) also reported that oleuropein showed the highest levels among the other phenolics in the olive fruits. Statistically significant differences among the four varieties studied in regards to their phenolic constituent levels were observed. Kargaburun and Saurani had higher levels of luteolin, h-phenyl acetic acid, tyrosol, verbascoside; the fruits of the Kargaburun variety had apigenin, cinnamic acid, $\mathrm{H}$-tyrosol, taxifolin; the fruits of Saurani had luteolin and hydroxybenzoic acid (h-benzoic acid) values higher than the values of other varieties. Halhalı fruits had the highest value of caffeic and syringic acids, with the Kargaburun and Saurani fruits following the Halhalı fruits. The fruits of the Erkence and Saurani varieties had the highest levels of vanillic acid. Sauranifruits had the highest oleuropein concentration while Erkence showed the lowest values of oleuropein. Regarding rutin content, the values were apparently not affected by the nature of the variety. It can be concluded that the Kargaburun and Saurani fruits contained higher levels of the analyzed individual phenolics than the Erkence and Halhalı fruits.

In general, the phenolic constituents showed a decreasing trend according to the HDs. The fruits had the highest level of verbascoside at the second $\mathrm{HD}$, whereas 4-h-phenyl acetic acid had the lowest levels in the fruits on the second HD. The amounts of phenolics compounds such as caffeic acid, vanilic acid, tyrosol and $\mathrm{H}$-tyrosol decreased as the fruits ripened except for the Saurani variety. $\mathrm{H}$-benzoic acid, cinnamic acid and $p$-coumaric acid levels decreased too, but the first two compounds showed a rise in the Halhalı variety and the latter did not show a significant change in the Erkence variety. The oleuropein and rutin contents of the fruits showed the highest levels on the second HD, similar to verbascoside and h-phenyl acetic acid. But in the fruits of the Erkence variety, oleuropein 


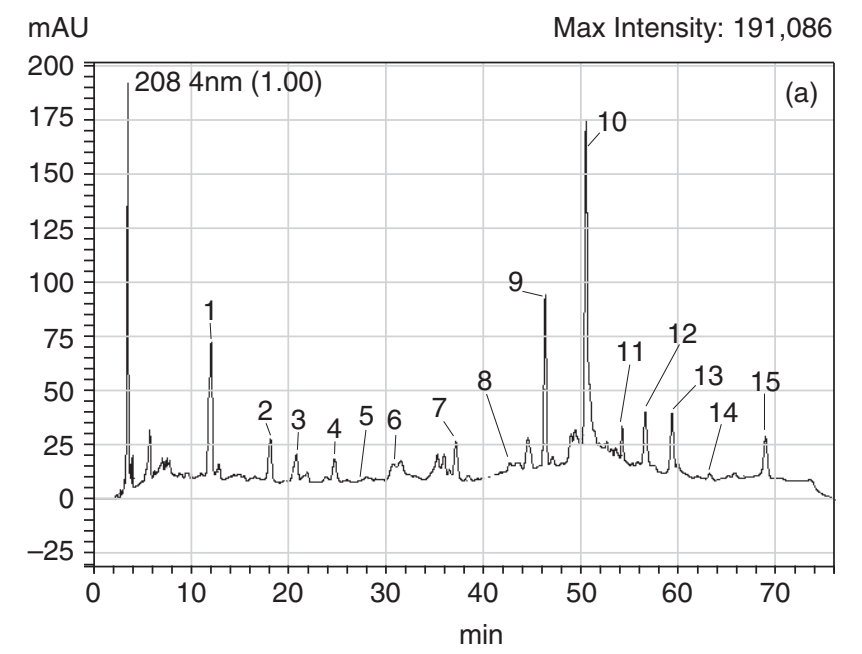

mAU

Max Intensity: 197,400

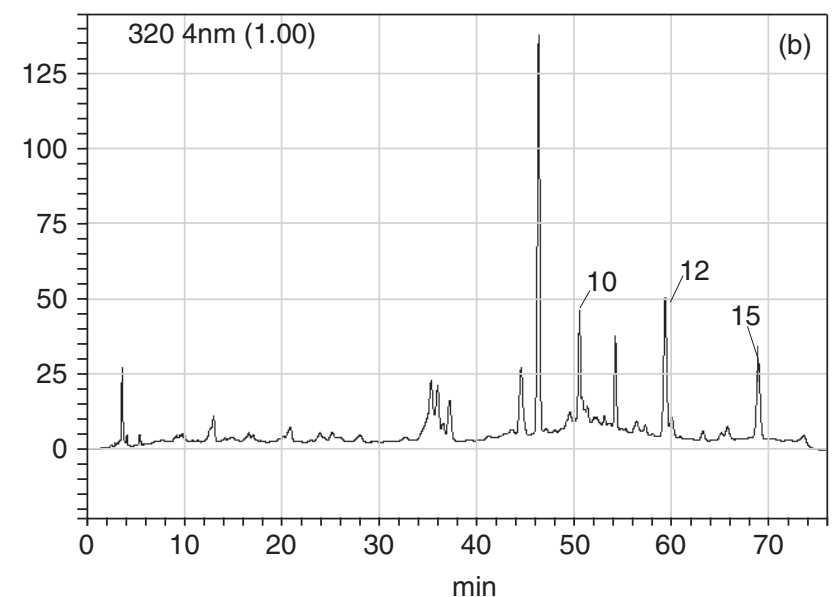

Figure 2

Chromatographic profiles of the phenolic compounds from the olive fruits. (a) $280 \mathrm{~nm}$ (b) $320 \mathrm{~nm}$.

(1) Hydroxytyrosol; (2) tyrosol; (3) 4-hydroxyphenyl acetic acid; (4) vanillic acid; (5) caffeic acid; (6) syringic acid; (7) p-coumaric acid; (8) taxifolin; (9) verbascoside; (10) rutin; (11) oleuropein; (12) luteolin; (13) cinnamic acid; (14) 3,4-hydroxybenzoic acid; (15) apigenin.

and rutin concentrations increased in further HDs. Our results for some varieties do not confirm what was reported by Boskou (2006) and Ryan et al. (1999) where the authors claimed that oleuropein content decreases and tyrosol and $\mathrm{H}$-tyrosol contents increase during the ripening of olive fruits. In the case of verbascoside, Ryan et al.(1999) reported similar results as the content of this phenolic compound decreases when the HD moves on.

Gómez-Rico et al.(2008) reported that an inverse relationship exists between oleuropein and verbascoside contents, the variety exhibiting the highest verbascoside content and lowest level of oleuropein and that the variety richest in oleuropein had the lowest verbascoside content. The same relationship was observed in the present study. Erkence and Saurani varieties, which had higher average verbascoside contents, exhibited lower values of average oleuropein contents than the other two varieties. Gómez-Rico et al. (2008) concluded that the oleuropein content in the fruits of six different Spanish varieties decreased during the course of ripening which is in agreement with the values for Halhalı and Saurani varieties in this study. Gómez-Rico et al. (2008) and Artajo et al. (2006) also reported that there were clear increases in the concentrations of $\mathrm{H}$-tyrosol, verbascoside, rutin and luteolin during fruit ripening. These compounds showed similar trends in the present

Table 2

Some phenolic constituents in olive fruit samples

\begin{tabular}{|c|c|c|c|c|c|c|c|c|c|c|c|c|}
\hline & \multicolumn{12}{|c|}{ Varieties } \\
\hline & \multicolumn{3}{|c|}{ Kargaburun } & \multicolumn{3}{|c|}{ Erkence } & \multicolumn{3}{|c|}{ Halhalı } & \multicolumn{3}{|c|}{ Saurani } \\
\hline & $1\left(\mathbf{R}^{\dagger}=1.5\right)$ & $2(\mathrm{RI}=3.5)$ & $3(\mathrm{RI}=5.5)$ & $1(R \mid=1)$ & $2(R I=4)$ & $3(\mathrm{RI}=6)$ & $1(R \mid=1)$ & $2(\mathrm{RI}=3.5)$ & $3(\mathrm{RI}=5.9)$ & $1(R \mid=2)$ & $2(\mathrm{RI}=4)$ & $3(\mathrm{RI}=6)$ \\
\hline Luteolin & $23.7 \pm 5.1^{\star} a$ & $13.6 \pm 1.7 \mathrm{~b}$ & $13.6 \pm 1.5 b$ & $8.6 \pm 1.1$ & $10.2 \pm 1.2$ & $7.5 \pm 1.4$ & $11.7 \pm 1.8 \mathrm{a}$ & $4.3 \pm 0.6 b$ & $6.6 \pm 1.1 b$ & $12.4 \pm 1.0 \mathrm{c}$ & $20.5 \pm 3.7 b$ & $36.8 \pm 5.8 a$ \\
\hline Apigenin & $6.1 \pm 0.6 a$ & $1.9 \pm 0.2 b$ & $2.3 \pm 0.2 b$ & $1.1 \pm 0.2 b$ & $2.0 \pm 0.2 a$ & $1.2 \pm 0.2 b$ & $0.5 \pm 0.1 b$ & $3.3 \pm 0.3 a$ & $0.9 \pm 0.1 b$ & $0.1 \pm 0.0 \mathrm{~b}$ & $2.1 \pm 0.4 a$ & $2.5 \pm 0.3 a$ \\
\hline Verbascosid & $1.3 \pm 0.3 b$ & $1.9 \pm 0.2 \mathrm{a}$ & $0.6 \pm 0.2 c$ & $1.3 \pm 0.2 b$ & $1.9 \pm 0.2 \mathrm{a}$ & $1.1 \pm 0.2 b$ & $0.6 \pm 0.1 b$ & $1.2 \pm 0.2 \mathrm{a}$ & $0.7 \pm 0.2 b$ & $0.3 \pm 0.1 \mathrm{c}$ & $2.8 \pm 0.5 a$ & $1.0 \pm 0.1 b$ \\
\hline Cinnamic acid & $0.7 \pm 0.1 \mathrm{a}$ & $0.2 \pm 0.0 b$ & $0.1 \pm 0.0 \mathrm{c}$ & $0.3 \pm 0.1 a$ & $0.2 \pm 0.0 \mathrm{a}$ & $0.1 \pm 0.0 b$ & $0.2 \pm 0.0 \mathrm{~b}$ & $0.3 \pm 0.0 \mathrm{a}$ & $0.1 \pm 0.0 b$ & $0.2 \pm 0.0 \mathrm{a}$ & $0.1 \pm 0.0 \mathrm{~b}$ & $0.1 \pm 0.0 b$ \\
\hline $\begin{array}{l}\text { 4-hydroxy phenyl } \\
\text { acetic acid }\end{array}$ & $28.6 \pm 4.2 \mathrm{a}$ & $13.7 \pm 2.6 b$ & $31.9 \pm 4.1 a$ & $15.6 \pm 2.9 \mathrm{a}$ & $2.5 \pm 0.7 b$ & $15.0 \pm 3.3 a$ & $8.4 \pm 0.9 b$ & $15.5 \pm 3.4 a$ & $7.3 \pm 1.5 b$ & $25.4 \pm 3.8 b$ & $9.2 \pm 1.7 c$ & $45.3 \pm 4.9 a$ \\
\hline $\begin{array}{l}\text { 3-4-Hydroxybenzoic } \\
\text { acid }\end{array}$ & $7.9 \pm 0.5 a$ & $2.0 \pm 0.4 b$ & $1.2 \pm 0.1 c$ & $3.8 \pm 0.4 a$ & $1.6 \pm 0.0 b$ & $2.2 \pm 0.6 b$ & $2.4 \pm 0.1 b$ & $5.7 \pm 0.5 a$ & $5.6 \pm 0.2 \mathrm{a}$ & $7.3 \pm 0.5 a$ & $4.7 \pm 0.6 b$ & $4.5 \pm 0.9 b$ \\
\hline Caffeic acid & $0.5 \pm 0.1 \mathrm{a}$ & $0.1 \pm 0.0 \mathrm{c}$ & $0.3 \pm 0.0 b$ & $0.4 \pm 0.0 \mathrm{a}$ & $0.1 \pm 0.0 c$ & $0.2 \pm 0.0 b$ & $0.1 \pm 0.0 \mathrm{c}$ & $1.3 \pm 0.1 a$ & $0.4 \pm 0.0 b$ & $0.1 \pm 0.0 \mathrm{c}$ & $0.3 \pm 0.0 \mathrm{~b}$ & $1.0 \pm 0.0 \mathrm{a}$ \\
\hline H-Tyrosol & $84.5 \pm 3.5$ & $79.3 \pm 5.8$ & $75.7 \pm 10.0$ & $97.7 \pm 10.2 \mathrm{a}$ & $78.9 \pm 5.9 b$ & $39.5 \pm 10.0 \mathrm{c}$ & $99.9 \pm 8.6 a$ & $42.2 \pm 4.4 b$ & $40.5 \pm 10.0 \mathrm{~b}$ & $18.3 \pm 4.4 \mathrm{c}$ & $47.5 \pm 8.5 b$ & $75.5 \pm 8.6 \mathrm{a}$ \\
\hline p-Coumaric acid & $2.6 \pm 0.5 b$ & $0.1 \pm 0.0 b$ & $0.5 \pm 0.1 a$ & $0.8 \pm 0.1$ & $0.6 \pm 0.1$ & $0.6 \pm 0.1$ & $0.4 \pm 0.0 \mathrm{a}$ & $0.1 \pm 0.0 \mathrm{~b}$ & $0.1 \pm 0.0 b$ & $1.1 \pm 0.1 \mathrm{a}$ & $0.2 \pm 0.0 \mathrm{c}$ & $0.5 \pm 0.1 b$ \\
\hline Syringic acid & $0.5 \pm 0.1 \mathrm{a}$ & $0.1 \pm 0.0 \mathrm{~b}$ & $0.5 \pm 0.1 \mathrm{a}$ & $0.4 \pm 0.0 a$ & $0.1 \pm 0.0 b$ & $0.1 \pm 0.0 b$ & $0.2 \pm 0.0 \mathrm{c}$ & $1.4 \pm 0.2 \mathrm{a}$ & $0.5 \pm 0.0 \mathrm{~b}$ & $0.0 \pm 0.0 \mathrm{c}$ & $0.3 \pm 0.1 b$ & $0.5 \pm 0.1 a$ \\
\hline Taxifolin & $0.4 \pm 0.1 b$ & $1.5 \pm 0.4 a$ & $0.7 \pm 0.2 b$ & $0.6 \pm 0.1 \mathrm{a}$ & $0.5 \pm 0.1 \mathrm{a}$ & $0.3 \pm 0.0 b$ & $0.5 \pm 0.1$ & $0.6 \pm 0.1$ & $0.5 \pm 0.1$ & $0.9 \pm 0.2 \mathrm{a}$ & $0.2 \pm 0.0 \mathrm{~b}$ & $0.7 \pm 0.1 a$ \\
\hline Tyrosol & $29.5 \pm 1.9 a$ & $9.2 \pm 1.4 b$ & $11.2 \pm 2.5 b$ & $13.9 \pm 0.9 a$ & $5.2 \pm 0.5 b$ & $6.1 \pm 2.0 b$ & $13.0 \pm 1.9 \mathrm{a}$ & $6.5 \pm 0.8 b$ & $3.4 \pm 0.4 c$ & $5.0 \pm 1.2 b$ & $9.3 \pm 0.8 b$ & $30.9 \pm 3.5 a$ \\
\hline Vanillic acid & $5.0 \pm 0.4 a$ & $0.9 \pm 0.0 c$ & $2.0 \pm 0.3 b$ & $12.4 \pm 0.9 a$ & $4.3 \pm 0.7 b$ & $3.9 \pm 0.6 b$ & $5.6 \pm 0.7 a$ & $1.7 \pm 0.3 b$ & $1.9 \pm 0.3 b$ & $2.9 \pm 0.4 b$ & $2.8 \pm 0.3 b$ & $9.0 \pm 1.0 \mathrm{a}$ \\
\hline Oleuropein & $45.0 \pm 3.1 \mathrm{c}$ & $120.8 \pm 11.4 a$ & $84.3 \pm 5.3 b$ & $41.4 \pm 1.3 b$ & $69.0 \pm 5.6 a$ & $68.1 \pm 5.1 a$ & $75.9 \pm 5.5 b$ & $115.7 \pm 7.3 a$ & $59.1 \pm 5.0 \mathrm{c}$ & $89.7 \pm 5.1 b$ & $159.7 \pm 34.4 a$ & $84.4 \pm 5.5 c$ \\
\hline Rutin & $4.3 \pm 0.3 c$ & $17.8 \pm 3.0 \mathrm{a}$ & $9.4 \pm 1.4 b$ & $5.1 \pm 0.5 b$ & $12.1 \pm 1.5 \mathrm{a}$ & $10.8 \pm 2.2 \mathrm{a}$ & $5.6 \pm 0.9 b$ & $13.8 \pm 3.1 a$ & $8.9 \pm 1.7 b$ & $3.6 \pm 1.0 \mathrm{c}$ & $13.7 \pm 0.7 a$ & $6.9 \pm 1.2 b$ \\
\hline
\end{tabular}

${ }^{*}$ mean \pm standard deviation, ${ }^{\dagger} \mathrm{RI}=$ Ripening index. 
study. For example, increases were detected in the $\mathrm{H}$-tyrosol and luteolin contents in the Saurani fruits, verbascoside in Halhalı and Saurani fruits and rutin in all four varieties as the HD moved on.

\subsection{Organic acids}

The average total organic acid content in the olive fruits ranged from 3280 to $7088 \mathrm{mg} / \mathrm{kg}$ (Table 3). The organic acids in the olive fruits were determined in the order: citric $>$ succinic $>$ galacturonic $>$ lactic $>$ malic $=$ tartaric acid. Saurani fruits had the highest levels of lactic, citric, succinic and tartaric acids. Halhalı fruits also had high concentrations of lactic and tartaric acids.

Citric, galacturonic and succinic acids had the highest levels on the second HD in all the varieties. The amounts of these acids decreased on the third HD. Malic acid showed an increase when the HD moved on; this increase was steady in the Kargaburun and Erkence varieties while the Halhalı and Saurani varieties had the highest amounts of malic acid on the second HD.

The tartaric acid contents of the Erkence and Halhalı varieties decreased with the ripening process. In the Kargaburun and Saurani varieties, tartaric acid reached its highest levels on the second HD, but then decreased on the third HD. The oxalic acid level steadily decreased throughout the fruit maturation or harvest time continuum in all varieties, except for the Erkence variety whose oxalic acid content did not show a significant change with regard to HD. Lactic acid showed a steady decrease in the Kargaburun and Saurani varieties and a steady increase in the Halhalı and Erkence varieties.

In general, oxalic and tartaric acids decreased when the harvesting date moved on but malic acid showed increase in all the varieties. Citric, galacturonic and succinic acids were present at low levels on the first HD then their levels increased on the second HD and eventually decreased on the last HD.

There are not many studies related to the organic content in olive fruits. Almost all the published studies are mostly concerning table olives which were subjected to a fermentation process. One of the very few studies about these compounds belongs to Cunha et al. (2001), who reported the citric, lactic and succinic acid values $(\mathrm{mg} / 100 \mathrm{~g})$ in commercial green table olives from the Portuguese market as between 214.1 and 477.3, 0 and 188.3 and 0 and 25.8, respectively. In our study, these values varied from 1149.2 to $5331.2,19.7$ to 707.0 and 546.8 to $2026.7 \mathrm{mg} / 100 \mathrm{~g}$. Undoubtedly the biggest reason for the differences among the values is the use of non fermented raw olives in the assay. The variety, origin, ripeness of the fruits and the analysis methods should also be taken into account while comparing the results. Nergiz and Ergönül (2009) reported the oxalic, citric, malic and succinic acids in the Turkish olive varieties Domat, Gemlik and Uslu as between 6.6 and 345.0, 417.0 and 4637.5, 764.5 and 4310.0 and 389.0 and 1643.5. The total organic acid contents of these three olive varieties were also reported to show a decreasing trend in the first 3 months of maturation and then an increase for all the varieties, except Uslu. They also reported that there had been irregular changes in the contents of individual organic acids of olives during maturation. The values obtained in the present study are closer to the values reported by Nergiz and Ergönül (2009) and, in addition, the same irregular changes in organic acids during fruit ripening were observed.

\subsection{Fatty acid compositions}

As shown in Table 4, palmitic, oleic and linoleic acids were measured as major fatty acids. The level of palmitic acid ranged from 8.97 to $14.77 \%$ and the Halhalı and Saurani varieties had the highest average levels among the four varieties; whereas the remaining two varieties, Kargaburun and Erkence, showed the highest stearic acid percentage. Linoleic acid, especially on the first two harvest dates, was high in Halhalı and Erkence oils as the average ratios of the three harvest dates were $10.55 \%$ and $9.67 \%$, respectively. The contents of the other fatty acids: palmitoleic $(0.66-6.16 \%)$, stearic $(1.89-5.24 \%)$, linolenic (0.83-1.02\%) and arachidic (0.43-0.58\%), although varying from one olive oil to another, were fairly small. As compared to the oils of the Saurani and Kargaburun varieties, the Halhalı and Erkence varieties produced oils with lower levels of oleic acid

Table 3

Organic acid concentrations ( $\mathrm{mg} / 100 \mathrm{~g}$ fresh weight) in olive fruit samples

\begin{tabular}{|c|c|c|c|c|c|c|c|c|c|c|c|c|}
\hline & \multicolumn{12}{|c|}{ Varieties } \\
\hline & \multicolumn{3}{|c|}{ Kargaburun } & \multicolumn{3}{|c|}{ Erkence } & \multicolumn{3}{|c|}{ Halhalı } & \multicolumn{3}{|c|}{ Saurani } \\
\hline & $1\left(\mathrm{RI}^{\dagger}=1.5\right)$ & $2(\mathrm{RI}=3.5)$ & $3(\mathrm{RI}=5.5)$ & $1(\mathrm{RI}=1)$ & $2(\mathrm{RI}=4)$ & $3(\mathrm{Rl}=6)$ & $1(\mathrm{Rl}=1)$ & $2(\mathrm{RI}=3.5)$ & $3(\mathrm{Rl}=5.9)$ & $1(\mathrm{RI}=2)$ & $2(\mathrm{Rl}=4)$ & $3(\mathrm{RI}=6)$ \\
\hline Citric acid & $1149.2 \pm 73.7^{*} \mathrm{C}$ & $5331.2 \pm 592.5 \mathrm{a}$ & $2264.0 \pm 111.4 b$ & $1942.2 \pm 318.0 \mathrm{ab}$ & $2456.5 \pm 313.0 \mathrm{a}$ & $1698.5 \pm 247.3 b$ & $1676.8 \pm 103.2 b$ & $3490.8 \pm 203.1 a$ & $1871.3 \pm 568.0 \mathrm{~b}$ & $5148.8 \pm 418.7 a$ & $1937.7 \pm 552.9 b$ & $1940.2 \pm 75.0$ \\
\hline $\begin{array}{l}\text { Galacturonic } \\
\text { acid }\end{array}$ & $263.0 \pm 29.8 \mathrm{c}$ & $2115.2 \pm 364.4 a$ & $708.8 \pm 54.6 b$ & $453.0 \pm 13.4 b$ & $1267.0 \pm 145.4 a$ & $504.0 \pm 19.0 \mathrm{~b}$ & $248.0 \pm 35.4 b$ & $372.8 \pm 54.8 \mathrm{a}$ & $144.5 \pm 16.4 c$ & $228.7 \pm 204.4 b$ & $828.3 \pm 410.7 a$ & $177.3 \pm 37.4$ \\
\hline Lactic acid & $550.7 \pm 83.0 \mathrm{a}$ & $19.7 \pm 4.0 \mathrm{c}$ & $289.3 \pm 25.1 b$ & $95.0 \pm 14.3 b$ & $73.3 \pm 12.3 b$ & $707.0 \pm 99.6 a$ & $53.8 \pm 3.6 \mathrm{c}$ & $603.2 \pm 16.0 \mathrm{a}$ & $441.2 \pm 20.0 \mathrm{~b}$ & $514.5 \pm 12.0 \mathrm{a}$ & $339.7 \pm 27.7 b$ & $203.7 \pm 26.60$ \\
\hline Malic acid & $65.8 \pm 10.7 \mathrm{c}$ & $359.7 \pm 43.1 b$ & $432.8 \pm 28.1 a$ & $37.8 \pm 1.0 \mathrm{c}$ & $223.5 \pm 10.0 \mathrm{~b}$ & $545.8 \pm 27.5 a$ & $372.8 \pm 10.3 a$ & $147.3 \pm 31.4 \mathrm{c}$ & $205.5 \pm 19.4 b$ & $216.7 \pm 46.5 b$ & $450.8 \pm 34.0 \mathrm{a}$ & $83.7 \pm 7.1 \mathrm{c}$ \\
\hline Oxalic acid & $128.7 \pm 17.6 \mathrm{a}$ & $30.0 \pm 3.3 c$ & $55.8 \pm 4.3 b$ & $46.5 \pm 4.3$ & $52.8 \pm 2.6$ & $48.2 \pm 5.0$ & $113.2 \pm 12.0 \mathrm{a}$ & $57.3 \pm 3.3 b$ & $46.3 \pm 3.5 b$ & $48.7 \pm 3.3 b$ & $121.5 \pm 13.0 \mathrm{a}$ & $50.5 \pm 3.5 b$ \\
\hline Succinic acid & $1038.3 \pm 111.8 \mathrm{a}$ & $546.8 \pm 84.9$ & $1093.5 \pm 58.9 \mathrm{a}$ & $821.5 \pm 61.7 \mathrm{~b}$ & $1338.2 \pm 235.8 \mathrm{a}$ & $818.0 \pm 52.9 b$ & $731.7 \pm 54.0 b$ & $1158.7 \pm 94.0 \mathrm{a}$ & $843.5 \pm 117.3 b$ & $745.0 \pm 42.4 b$ & $2026.7 \pm 158.4 a$ & $808.7 \pm 60.1$ \\
\hline Tartaric acid & $84.3 \pm 5.1 \mathrm{c}$ & $327.5 \pm 17.2 \mathrm{a}$ & $164.0 \pm 44.5 b$ & $237.3 \pm 21.4 a$ & $124.3 \pm 24.4 b$ & $151.8 \pm 25.9 b$ & $353.2 \pm 15.8 \mathrm{a}$ & $239.5 \pm 37.3 b$ & $195.0 \pm 4.4 b$ & $184.8 \pm 12.4 b$ & $378.8 \pm 10.3 a$ & $179.3 \pm 15.2$ \\
\hline
\end{tabular}


Table 4

Fatty acids composition of olive oils extracted from olive fruits of Hatay province

\begin{tabular}{|c|c|c|c|c|c|c|c|c|c|c|c|c|}
\hline \multirow{3}{*}{ Fatty acids } & \multicolumn{12}{|c|}{ Varieties } \\
\hline & \multicolumn{3}{|c|}{ Kargaburun } & \multicolumn{3}{|c|}{ Erkence } & \multicolumn{3}{|c|}{ Halhalı } & \multicolumn{3}{|c|}{ Saurani } \\
\hline & $1\left(\left.R\right|^{\dagger}=1.5\right)$ & $2(\mathrm{RI}=3.5)$ & $3(\mathrm{RI}=5.5)$ & $1(\mathrm{RI}=1)$ & $2(R I=4)$ & $3(\mathrm{RI}=6)$ & $1(R I=1)$ & $2(\mathrm{RI}=3.5)$ & $3(\mathrm{RI}=5.9)$ & $1(\mathrm{Rl}=2)$ & $2(\mathrm{RI}=4)$ & $3(\mathrm{RI}=6)$ \\
\hline palmitic & $8.97 \pm 1.41^{*} b$ & $12.77 \pm 1.48 \mathrm{a}$ & $11.55 \pm 0.51 \mathrm{ab}$ & $11.93 \pm 0.52$ & $11.73 \pm 0.05$ & $10.40 \pm 1.24$ & $14.77 \pm 0.64$ & $14.47 \pm 1.19$ & $13.26 \pm 0.74$ & $13.08 \pm 0.42 a b$ & $13.69 \pm 0.52 a$ & $11.43 \pm 1.11 b$ \\
\hline palmitoleic & $2.72 \pm 0.64 a$ & $1.69 \pm 0.13 b$ & $2.38 \pm 0.61 a b$ & $1.08 \pm 0.23$ & $1.21 \pm 0.33$ & $0.72 \pm 0.41$ & $6.16 \pm 4.45$ & $1.42 \pm 0.52$ & $1.07 \pm 0.07$ & $1.14 \pm 0.19 \mathrm{a}$ & $0.84 \pm 0.08 a b$ & $0.66 \pm 0.09 b$ \\
\hline stearic & $4.51 \pm 0.36 \mathrm{a}$ & $5.24 \pm 0.99 a$ & $3.66 \pm 0.45 b$ & $3.98 \pm 0.63$ & $3.44 \pm 0.42$ & $3.21 \pm 0.62$ & $2.51 \pm 0.36$ & $2.32 \pm 1.21$ & $2.27 \pm 0.80$ & $2.86 \pm 0.50 \mathrm{ab}$ & $3.47 \pm 0.80 \mathrm{a}$ & $1.89 \pm 0.25 b$ \\
\hline oleic & $75.61 \pm 1.68 \mathrm{a}$ & $69.29 \pm 0.94 b$ & $71.14 \pm 0.92 b$ & $69.07 \pm 3.44$ & $68.71 \pm 1.37$ & $70.94 \pm 2.29$ & $68.42 \pm 2.03$ & $67.25 \pm 0.44$ & $67.54 \pm 1.21$ & $71.24 \pm 1.11$ & $72.51 \pm 1.25$ & $70.70 \pm 0.56$ \\
\hline linoleic & $3.97 \pm 0.19 b$ & $6.82 \pm 0.47 a$ & $7.09 \pm 0.22 a$ & $9.38 \pm 1.18$ & $10.55 \pm 0.29$ & $9.09 \pm 0.59$ & $9.95 \pm 0.68$ & $10.60 \pm 1.00$ & $11.11 \pm 0.23$ & $5.44 \pm 0.62 b$ & $6.27 \pm 1.25 b$ & $11.25 \pm 1.07 a$ \\
\hline arachidic & $0.54 \pm 0.04 a b$ & $0.57 \pm 0.04 a$ & $0.45 \pm 0.03 b$ & $0.47 \pm 0.09$ & $0.58 \pm 0.03$ & $0.54 \pm 0.11$ & $0.52 \pm 0.04$ & $0.43 \pm 0.12$ & $0.57 \pm 0.03$ & $0.53 \pm 0.07$ & $0.49 \pm 0.07$ & $0.44 \pm 0.02$ \\
\hline linolenic & $0.99 \pm 0.15$ & $0.97 \pm 0.16$ & $0.85 \pm 0.03$ & $0.98 \pm 0.41$ & $0.96 \pm 0.17$ & $1.02 \pm 0.05$ & $0.92 \pm 0.20$ & $1.00 \pm 0.05$ & $0.90 \pm 0.12$ & $1.02 \pm 0.13 a$ & $0.83 \pm 0.09 b$ & $0.85 \pm 0.02 a b$ \\
\hline
\end{tabular}

${ }^{*}$ mean \pm standard deviation, ${ }^{\dagger} \mathrm{Rl}=$ Ripening index.

at around $68 \%$. The remaining oils showed high oleic acid levels rising to $75 \%$ for the Kargaburun variety on the first harvest date. Arachidic and linolenic acid concentrations did not significantly differ among the varieties. On comparing the results by harvest time, significant differences can be seen among the three dates in the fatty acid compositions of the oils. Palmitic and stearic acid levels generally decreased along the fruit maturation or harvest time continuum in all varieties.

There were steady raises in the linoleic acid ratios of the Saurani and Kargaburun oils when the harvest time goes further, whereas these raises were not statistically significant for the Erkence and Halhalı varieties. The increase in linoleic acid content is due to the fact that, besides the continuing biosynthesis of triglycerides, with the formation of oleic acid, the enzyme oleate desaturase is active, transforming oleic acid into linoleic (Gutiérrez et al., 1999). The oleic acid level decreased when harvest time progressed for Kargaburun oils, where there were no significant changes in the oleic acid levels in the oils of the other varieties. There are studies on the fatty acid compositions of olive oils which report that the oleic acid percentage increases (Cossignani et al., 2001, Shibasaki, 2005) while other studies report decreases (Baccouri et al., 2008) in the level of oleic acid with ripeness or harvest time. Nonetheless, Finotti et al. (2001) reported that there was a decrease in the oleic acid level in the Lastorka variety, while there was not any significant change for the Buza variety in Croatia. Erkence and Halhalı variety oils did not show significant changes in terms of their fatty acids compositions when harvest time progressed.

\section{CONCLUSIONS}

The high pit and pulp weights and fruit, width, thickness and length values, dry matter, total oil, total phenolics and Trolox equivalent antioxidant activity contents as well as the analyzed individual phenolics (especially luteolin, verbascoside, tyrosol and h-phenyl acetic acid) of the Kargaburun and Saurani varieties makes the olives of these varieties superior to the Halhalı and Erkence varieties. The Saurani and Kargaburun varieties seem to have characteristic phenolic profiles: Saurani for its high amount of oleuropein, Kargaburun for its high level of $\mathrm{H}$-tyrosol. It is not possible to prove whether this is a characteristic of the cultivar or alternatively related to geographical origin; this can only be confirmed from more analysis in samples collected during future years. These two varieties produced oils with higher oleic acid levels among the four varieties.

Regarding the effect of harvest dates, pit and pulp weight, fruit width, thickness and length values and generally the total oil values of all the varieties were not significantly affected by the harvest time. The dry matter content of the fruits increased and total phenolics decreased with ripening, while neither showed significant changes during the course of ripening for the Erkence fruits. Some of the phenolic constituents (verbascoside, oleuropein, rutin and h-phenyl acetic acid) and organic acids (citric, galacturonic and succinic acids) were present at low levels on the first harvest date then their levels in the olive fruits increased on the second harvest date and eventually decreased on the last harvest date. Immature fruits had higher DPPH radical scavenging activities; on the contrary, they showed a lower antioxidant capacity than those of matured fruits. The fatty acid compositions of Halhalı and Erkence varieties were more stable regarding the changes due to harvest dates.

\section{ACKNOWLEDGEMENT}

This study was supported by Selcuk University Office of Scientific Research Projects (S.Ü. BAP, Konya-Turkey).

\section{REFERENCES}

Anonymous1991. Standart Zeytin Çeşitleri Katalogu. Tarım ve Köyişleri Bakanlığı Yayınları. No: 334, Seri:16. Ankara. pp. 107.

AOAC1990.Official methods of analysis, 14th edition. Association of Official Agricultural Chemists, Official Methods of Analysis, Washington DC, USA. 
Artajo LS, Romero MP, Motilva MJ. 2006. Transfer of phenolic compounds during olive oil extraction in relation to ripening stage of the fruit. J. Sci. Food Agric. 86, 518-527.

Baccouri O, Guerfel M, Baccouri B, Cerretani L, Bendini A, Lercker G, Zarrouk M, Miled DDB. 2008. Chemical composition and oxidative stability of Tunisian mono varietal virgin olive oils with regard to fruit ripening. Food Chem. 109, 743-754.

Beltrán G, Del Rio C, Sánchez S, Martínez L. 2004. Seasonal changes in olive fruit characteristics and oil accumulation during ripening process. J. Sci. Food Agric. 84,1783-1790.

Boskou D. 2006. Olive oil chemistry and technology. AOCS Press, Champaign, IL, 268, USA. Cerretani L, Bendini A, Rotondi A, Mari M, Lercker G,Gallina T. 2004. Evaluation of the oxidative stability and organoleptic properties of extra-virgin olive oils in relation to olive ripening degree. Progr. Nutr. 6, 50-56.

Cossignani L,Simonetti MS, DamianiP. 2001. Structural changes of triacylglycerol and diacylglycerol fractions during olive drupe ripening. Eur. Food Res. Technol. 212, 160-164.

Criado MN, Motilva MJ, Goñi M, Romero MP. 2007. Comparative study of the effect of the maturation process of the olive fruit on the chlorophyll and carotenoid fractions of drupes and virgin oils from Arbequina and Farga cultivars. Food Chem. 100, 748-755.

Cunha SC, Ferreira IMP, Fernandes JO, Faria MA, Beatriz M, Oliveira PP.2001. Determination of lactic, acetic, succinic, and citric acids in table olives by HPLC/UV. J. Chrom. Relat. Techn. 24, 1029-1038.

Dabbou S, Sifi S, Rjiba I, Esposto S, Taticchi A, Servili M, Montedoro, GF, Hammami M. 2010. Effect of pedoclimatic conditions on the chemical composition of the Sigoise olive cultivar. Chem. Biod. 7, 898-908.

DIE (Devlet İstatistik Enstitüsü, Turkish Statistical Institute) 2008. Tarım İstatistikleri Özeti 2008, Ankara, Türkiye.

Dıraman H. 2007. Gemlik zeytin cesidinden uretilen naturel zeytinyaglarinin oksidatif stabilitelerinin diger önemli yerli cesitler ile karsilastirilmasi. Gıda Tek. Elekt. Der. 3, 53-59.

Finotti E, Beye C, Nardo N, Quaglia GB, Milin C, Giacometti J. 2001. Physico-chemical characteristics of olives and olive oil from two mono-cultivars during various ripening phases. Nahrung/Food. 45, 350-352.

García JM, Seller S, Pérez-Camino MC. 1996. Influence of fruit ripening on olive oil quality. J. Agric. Food Chem. 44, 3516-3520.

Gómez-Rico A, Fregapane G, Salvador MD. 2008. Effect of cultivar and ripening on minor components in Spanish olive fruits and their corresponding virgin olive oils. Food Res. Int. 41, 433-440.

Gutiérrez F, Arnaud T, Albi MA. 1999. Influence of ecologic cultivation on virgin olive oil quality. J. Am. Oil Chem. Soc. 76, 617-621.

Kafkas E, Koşar M, Türemis N, Başer KHC. 2006. Analysis of sugars, organic acids and vitamin $\mathrm{C}$ contents of blackberry genotypes from Turkey. Food Chem. 97, 732-736.

Manai H, Haddada FM, Trigui A, Zarrouk DDM. 2007. Compositional quality of virgin olive oil from two new Tunisian cultivars obtained through controlled crossings. J. Sci. Food Agric. 87, 600-606.
Miller N, Rice-Evans C. 1997. Factors influencing the antioxidant activity determined by the $\mathrm{ABTS}^{\circ}$ radical cation assay. Free Radic. Res. 26, 195-199.

Nergiz C,Ergönül PG. 2009. Organic acid content and composition of the olive fruits during ripening and its relationship with oil and sugar. Sci. Hortic. 122, 216220.

Ocakoglu D, Tokatlı F, Ozen B, Korel F. 2009.Distribution of simple phenols, phenolic acids and flavonoids in Turkish monovarietal extra virgin olive oils for two harvest years. Food Chem. 113, 401-410.

Rial JD, Falque E. 2003. Characteristics of olive fruits and extra-virgin olive oils obtained from olive trees growing in Appellation of Controlled Origin 'Sierra Magina'. J. Sci. Food Agric. 83, 912-919.

Romero C, García P, Brenes M, García A, Garrido A. 2002. Phenolic compounds in natural black Spanish olive varieties. Eur. Food Res. Technol. 215, 489-496.

Ryan D, Robards K, Lavee S. 1999.Changes in phenolic content of olive during maturation. Int. J. Food Sci. Technol. 34, 265-274.

Sakouhi F, Harrabi S, Absalon C, Sbei K, Boukhchina S, Kallel H. 2008. $\alpha$-Tocopherol and fatty acids contents of some Tunisian table olives (Olea europea L.): Changes in their composition during ripening and processing. Food Chem. 108, 833-839.

Servili M, Baldioli M, Selvaggini R, Miniati E, Macchioni A, Montedoro G. 1999. High-performance liquid chromatography evaluation of phenols in olive fruit, virgin olive oil, vegetation waters, and pomace and 1D and 2D nuclear magnetic resonance characterization. J. Am. Oil Chem. Soc. 76, 873-882.

Shibasaki H. 2005. Influence of fruit ripening on chemical properties of 'Mission' variety olive oil in Japan. Food Sci. Technol. Res. 11, 9-12.

Singh RP, Murthy KNC, Jayaprakasha GK. 2002. Studies on the antioxidant activity of pomegranate (Punica granatum) peel and seed extracts using in-vitro models. J. Agric. Food Chem. 50, 81-86.

Stefanoudaki E, Kotsifaki F, Koutsaftakis A. 1999. Classification of virgin olive oils of the two major Cretan cultivars based on their fatty acid composition. J. Am. Oil Chem. Soc. 76, 623-626.

Tous J, Romero A. 1994. Cultivars and location effects on olive oil quality in Catalonia (Spain). Horticulturae. 356, 323-326.

Vázquez Roncero A, Janer del Valle C, Janer del Valle ML. 1973. Determinación de los polifenoles totales del aceite de oliva. Grasas y Aceites. 24, 350-357.

Vinha AF, Ferreres F, Silva BM, Valentao P, Goncalves A, Pereira JA, Oliveira MB, Seabra RM, Andrade PB. 2005. Phenolic profiles of Portuguese olive fruits (Olea europaea L.): Influences of cultivar and geographical origin. Food Chem. 89, 561-568.

ZAE Olive Research Institute of Turkey 2007. Economics and Statistics of Olive Oil in the World and Turkey. http://www.zae.gov.tr. Accessed Jan 2007.

Zamora R, Alaiz M, Hidalgo FJ. 2001. Influence of cultivar and fruit ripening on olive (Olea europaea L.) fruit protein content, composition and antioxidant activity. J. Agric. Food Chem. 49, 4267-4270.

Recibido: 14/7/11 Aceptado: 8/11/11 